\title{
P1-02
}

\section{IL-6 刺激によるヒト末梢血単核球の骨芽細胞様細胞への分化誘導と機能解析}

\section{$\bigcirc$ 横田和浩 ${ }^{1}$, 相崎良美 ${ }^{1}$, 秋山雄次 ${ }^{1,2}$, 三村俊英 ${ }^{1}$}

('埼玉医科大学 リウマチ膠原病科, ${ }^{2}$ 小川赤十字病院 リウマチ科)

【目的】自己免疫性疾患の一つである関節リウマチでは IL-6 等の炎症性サイトカインが病態の進展に重 要な役割を演じている。この炎症性サイトカインは心血管疾患 (CVD) 発症に強く関与し, CVD の危 険因子は血管石灰化である。血管石灰化は骨形成に類似した機序であり，血管組織に骨芽細胞様細胞 が存在することが知られている。そこでヒト末梢血単核球を用いて，IL-6 刺激による骨芽細胞様細胞 への分化誘導・機能を解析した。【方法】末梢血は健常人より採取し, 比重遠心法にて分離した単核球 を象牙質上に IL-6 または RANKL で刺激·培養した。形成された石灰化構造物を電子顕微鏡で観察し,

構成元素と濃度を調べた。培養単核球細胞におけるALP の活性を測定し，Runx2, Osterix mRNAの発 現量を real-time PCR 法で解析した.【結果】末梢血単核球を象牙質上で培養し，IL-6 で刺激すると石灰 化構造物の形成を認め，構成元素の解析では，主にカルシウム，リンが含まれていたＩL-6で刺激さ れた末梢血単核球は, ALP の活性およびRunx2, Osterix mRNAの発現量が無刺激・RANKL 刺激と比 較して有意に増加していた。【考察】末梢血単核球を IL-6 で刺激すると石灰化構造物を形成する骨芽細 胞様細胞が分化誘導された。このことは IL-6 が血管石灰化に関与している可能性を示唆している. 